Aktivitas antibakteri E. coli pada minyak atsiri... (Sherlly M. F. Ledoh, dkk.)

\title{
AKTIVITAS ANTIBAKTERI Eschericia coli PADA MINYAK ATSIRI BATANG GENOAK (Acorus calamus) ASAL PULAU TIMOR
}

\author{
Sherlly M. F. Ledoh*, Reiner I. Lerrick, Debora Ratu \\ Jurusan Kimia, Fakultas sains dan Teknik, Universitas Nusa Cendana, Kupang-NTT \\ email: sherlly305@gmail.com
}

\begin{abstract}
ABSTRAK
Telah dilakukan uji aktivitas antibakteri Eschericia coli (E. coli) minyak batang genoak (Acorus calamus). Penelitian ini dilakukan melalui destilasi uap batang genoak yang diikuti analisis komposisi kimianya menggunakan GC-MS, dan uji antibakteri terhadap bakteri $E$. coli menggunakan metode hitung cawan. Hasil penelitian diperoleh minyak genoak dengan rendemen $0,17 \%$ dan asaron sebagai komponen utama minyak genoak sebesar $89,81 \%$. Minyak genoak dapat menghambat pertumbuhan bakteri E. coli sebesar $95,76 \%$ pada kosentrasi $10 \%(\mathrm{v} / \mathrm{v})$.
\end{abstract}

Kata kunci : Destilasi uap, Batang Genoak (Acorus calamus), E. coli, Asaron.

\section{THE ANTI Eschericia coli STUDY OF GENOAK(Acorus calamus) OIL FROM TIMOR}

\begin{abstract}
The study of anti Eschericia coli (E. coli) of genoak oil (Acorus calamus) has been done. The research aimed to emerge the potential characteristic of genoak oil which distilled from its stem part. The anti bacterial study was done using plate count method, whilist the chemical compound contained in the oil was investigated using GC-MS. The research result show that asaron in the major compound in stem part of genoak i.e. $89.81 \%$. The genoak oil inhibited $95.76 \%$ of the E. coli growth at $10 \%$ (v/v) of its concentration.
\end{abstract}

Key words : Water Distillation, Genoak Stem, E. coli, Asaron.

\section{PENDAHULUAN}

Di Asia Tenggara, khususnya Indonesia merupakan negara yang kaya keanekaragaman tanaman aromatik. Indonesia menduduki peringkat tertinggi dalam perdagangan untuk sejumlah minyak atsiri. Beberapa jenis tanaman aromatik yang dapat menghasilkan minyak atsiri antara lain sereh, cengkeh, kenanga, cendana.

Salah satu jenis tanaman aromatik yang potensial dan telah dikembangkan adalah tanaman Acorus calamus atau dikenal juga dengan nama lokal Jeringau/deringu (Sunda), Dlingo (Jawa), Genoak (Timor), Jangu (Bali). Di pulau Timor, tanaman Genoak khusus bagian batangnya telah digunakan sebagai obat tradisional yaitu untuk mengobati sakit perut, masuk angin dan lain-lain. Tanaman genoak dibudidayakan secara tradisional sehingga belum dapat meningkatkan perekonomian 
masyarakat Indonesia khususnya pulau Timor.

Beberapa penelitian telah menunjukkan bahwa minyak Acorus calamus memiliki sifat antibakteri yang cukup kuat (Bhuvaneswari, 2012). Selain itu, minyak Acorus calamus juga menunjukkan aktivitas biologis seperti insektisida dan antelmintika. Oleh karena itu penulis memandang perlu untuk melakukan penelitian mengenai uji aktivitas antibakteri E. coli minyak genoak (Acorus calamus) hasil destilasi uap batang genoak. Penelitian ini diharapkan dapat meningkatkan ekonomi masyarakat melalui pengungkapan nilai ekonomis tanaman genoak yang selama ini hanya dianggap sebagai tanaman pengganggu/gulma oleh masyarakat Timor.

\section{METODE PENELITIAN}

\section{Alat dan Bahan}

Batang genoak, isolat bakteri E. coli, media agar, PDF (Peptone Dilution Fluid), akuades, PCA (Plate Count Agar), alkohol, petroleum eter, $\mathrm{Na}_{2} \mathrm{SO}_{4}$ anhidrat, Tween 80, parafin, TTC (1, 2, 3 Trifeniltetrazolium Klorida) 0,5 .

\section{Prosedur Penelitian}

\section{a. Isolasi dan identifikasi minyak atsiri}

Rimpang atau batang genoak diambil dan dibersihkan kemudian diiris tipis-tipis $\pm 2 \mathrm{~cm}$ dan dikeringkan beberapa hari tanpa cahaya matahari langsung. Sampel yang sudah dikeringkan ditimbang dan diperoleh sebanyak $4 \mathrm{~kg}$ kemudian diblender. Sebanyak $1 \mathrm{~kg}$ rimpang batang genoak dimasukan ke dalam labu destilasi dan dilarutkan dalam $5 \mathrm{~L}$ akuades. Hasil destilat berupa fraksi minyak dan fraksi air. Fraksi minyak kemudian dipisahkan dari faksi air berdasarkan densitas masing-masing fraksi. Fraksi minyak yang diperoleh selanjutnya dikeringkan dengan $\mathrm{Na}_{2} \mathrm{SO}_{4}$ anhidrat. Kandungan minyak dinyatakan sebagai rendemen dalam satuan gram minyak/gram sampel. Minyak yang diperoleh dianalisis komponen kimianya dengan menggunakan GCMS dan diuji aktivitas antimikrobanya.

\section{b. Pembuatan media dan pengujian} aktivitas antibakteri

\section{Pembuatan Media}

\section{a. Media PDF Steril}

Ditimbang $0,1 \quad \mathrm{~g} \quad$ PDF kemudian dimasukan ke dalam Erlenmeyer $250 \mathrm{~mL}$. Campuran tersebut kemudian dipanaskan dalam penangas air sampai membentuk larutan yang homogen. Sebanyak $9 \mathrm{~mL}$ larutan PDF tersebut di pipet ke dalam 10 tabung reaksi $25 \mathrm{~mL}$. Setiap tabung reaksi diberi label $10^{-1}-10^{-10}$ dan disterilisasi dalam autoclave.

\section{b. Media PCA Steril}

Ditimbang $9 \mathrm{~g}$ PCA dalam Erlenmeyer $500 \mathrm{~mL}$ kemudian ditambahkan $400 \mathrm{~mL}$ akuades dan dipanaskan dalam penangas air sampai membentuk larutan. Campuran di sterilisasi dalam autoclove. Dibuat juga media PCA steril lainnya sebanyak $200 \mathrm{~mL}$ dengan cara yang sama.

\section{Pengenceran bakteri}

Isolat bakteri E. coli dipindahkan ke dalam larutan PDF menggunakan kawat ose. Campuran bakteri dihomogen- 
kan. Ke dalam tabung reaksi $10^{-}$

${ }^{1}$ diisi dengan $0,1 \mathrm{~mL}$ larutan bakteri dan dihomogenkan.

Sebanyak 1,0 $\mathrm{mL}$ dari tabung $10^{-1}$ dipipet kedalam tabung reaksi $10^{-2}$ kemudian dihomogenkan. Perlakuan yang sama dilakukan hingga pada tabung $10^{-10}$

Dari setiap tabung reaksi diatas $\left(10^{-1}-10^{-10}\right)$ dipipet masingmasing $1,0 \quad \mathrm{~mL}$ untuk dimasukan dalam cawan petri yang telah diberi label $10^{-1}-10^{-10}$. Perlakuan dilakukan dua kali. Setelah itu ke dalam cawan petri tersebut ditambahkan media PCA steril dan dihomogenkan hingga memadat. Media kemudian diinkubasi selama 2 × 24 jam pada suhu $37{ }^{\circ} \mathrm{C}$. Lalu dihitung dengan menggunakan colony counter.

\section{Pengenceran sampel minyak atsiri batang genoak}

Minyak atsiri batang genoak ditambah dengan Tween 80 sebanyak $2 \mathrm{~mL}$, lalu ditambahkan parafin sebanyak $10 \mathrm{~mL}$ kemudian diaduk rata, setelah tercampur ditambahkan $5 \mathrm{~mL}$ akuades. Setelah tercampur rata larutan berubah menjadi cair dan berwarna putih susu.

\section{Uji aktivitas antibakteri}

Disiapkan 6 tabung reaksi $25 \mathrm{~mL}$ yang telah diberi label 0 , 2, 4, 6, 8 dan 10\%. Ke dalam tiap-tiap tabung reaksi tersebut ditambahkan $9 \mathrm{~mL}$ media PDF steril. Selanjutnya ke dalam tabung reaksi $10 \%$ ditambahkan $1 \mathrm{~mL}$ sampel minyak atsiri yang telah diencerkan kemudian dihomogenkan. Dari tabung reaksi $10 \%$ dipipet $2 \mathrm{~mL}$ ke dalam tabung reaksi $8 \%$ berturut-turut dilakukan hal yang sama untuk tabung reaksi 6,4 dan $2 \%$ dengan penambahan $4,6,8 \mathrm{~mL}$ sampel minyak atsiri.

Setelah itu larutan diaduk (Fortec Pixel) sehingga tercampur merata. Setelah tercampur dengan rata disiapkan sebanyak 10 cawan petri. Setiap cawan diberi tanda mulai dari konsentrasi 10\%-2\%, masing-masing 2 cawan untuk melihat perbandingan. Setelah itu sebanyak $2 \mathrm{~mL}$ sampel dari tabung yang berkonsentrasi $10 \%$ dipipet sebanyak $2 \mathrm{~mL}$ ke dalam 2 cawan petri masingmasing $1,0 \mathrm{~mL}$ yang diberi label $10 \%$ dan ke dalam cawan petri tersebut ditambahkan 1 $\mathrm{mL}$ larutan bakteri $10^{-4}$ koloni/mL. Hal yang sama dilakukan juga untuk sampel 8$2 \%$. Setelah itu ke dalam tiaptiap cawan petri dituangkan PCA $200 \mathrm{~mL}$ yang sebelumnya telah ditambahkan TTC 0,5 sebanyak $2 \mathrm{~mL}$ media kemudian didiamkan hingga memadat dan diinkubasikan pada suhu $37{ }^{\circ} \mathrm{C}$ selama $2 \times 24$ jam untuk kemudian dihitung bakteri yang tumbuh dengan menggunakan colony counter.

\section{HASIL DAN PEMBAHASAN}

\section{a. Hasil Destilasi Batang Genoak}

Destilasi dilakukan dengan sistem batch dimana jumlah sampel yang didestilasi tiap batch adalah $1 \mathrm{~kg}$ sampel batang genoak. Destilasi dengan sistem batch dilakukan sebanyak 4 kali sehingga total sampel batang genoak yang didestilasi sebanyak $4 \mathrm{~kg}$. Proses 
destilasi dihentikan dengan indikator kekeruhan. Kekeruhan destilat menunjukkan campuran minyak dan air sehingga jika destilat sudah tidak keruh, diasumsikan minyak batang genoak yang terkandung dalam sampel batang genoak telah habis terdestilasi. Adapun untuk setiap $1 \mathrm{~kg}$ sampel batang genoak, destilasi dilakukan selama lebih kurang 6 jam.

Minyak hasil destilasi diperoleh melalui pemisahan berdasarkan berat jenis minyak dan air. Minyak batang genoak terpisah dari air dan berada pada bagian atas. Minyak yang masih mengandung air dikeringkan melalui penambahan natrium sulfat anhidrous. Hasil destilasi sampel batang genoak diperoleh cairan bewarna kuning dengan bau yang khas dengan rendemen minyak yang diperoleh sebesar 0,17\%. Dari $4 \mathrm{~kg}$ sampel batang genoak kering diperoleh 6,68 gram minyak.

Identifikasi komponen kimia yang terkandung dalam minyak atsiri batang genoak dilakukan menggunakan instrumen gabungan kromtografi gas dan spektometer massa (GC-MS). Hasil analisis minyak batang genoak menggunakan GC-MS diperoleh kromatogram sebagaimana disajikan pada Gambar 1.

Dari Tabel 1 terlihat bahwa produk destilasi batang genoak relatif murni, yaitu dengan diperolehnya satu puncak yang sangat tinggi pada waktu retensi 23,514 menit (puncak 6) sedangkan puncak-puncak yang lainnya sangat rendah/kecil.

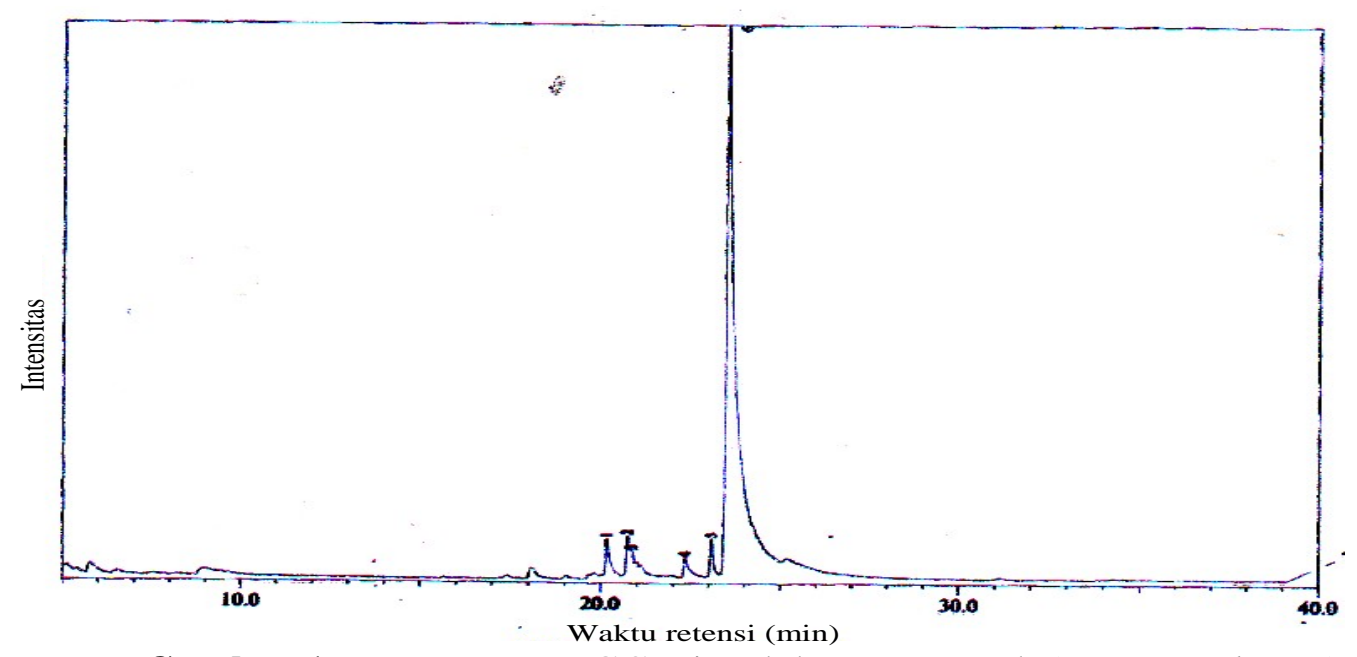

Gambar 1. Kromatogram GC minyak batang genoak (Acorus calamus)

Tabel 1. Waktu retensi dan prosentase senyawa dalam minyak batang genoak.

\begin{tabular}{|c|c|c|}
\hline $\begin{array}{c}\text { No. } \\
\text { Puncak }\end{array}$ & $\begin{array}{c}\text { Waktu Retensi } \\
\text { (menit) }\end{array}$ & $\begin{array}{c}\text { Prosentase } \\
\text { (\%) }\end{array}$ \\
\hline 1 & 20,171 & 3,32 \\
\hline 2 & 20,747 & 2,62 \\
\hline 3 & 20,875 & 0,86 \\
\hline 4 & 22,342 & 1,13 \\
\hline 5 & 23,073 & 2,35 \\
\hline 6 & 23,514 & 89,81 \\
\hline
\end{tabular}


Aktivitas antibakteri E. coli pada minyak atsiri... (Sherlly M. F. Ledoh, dkk.)

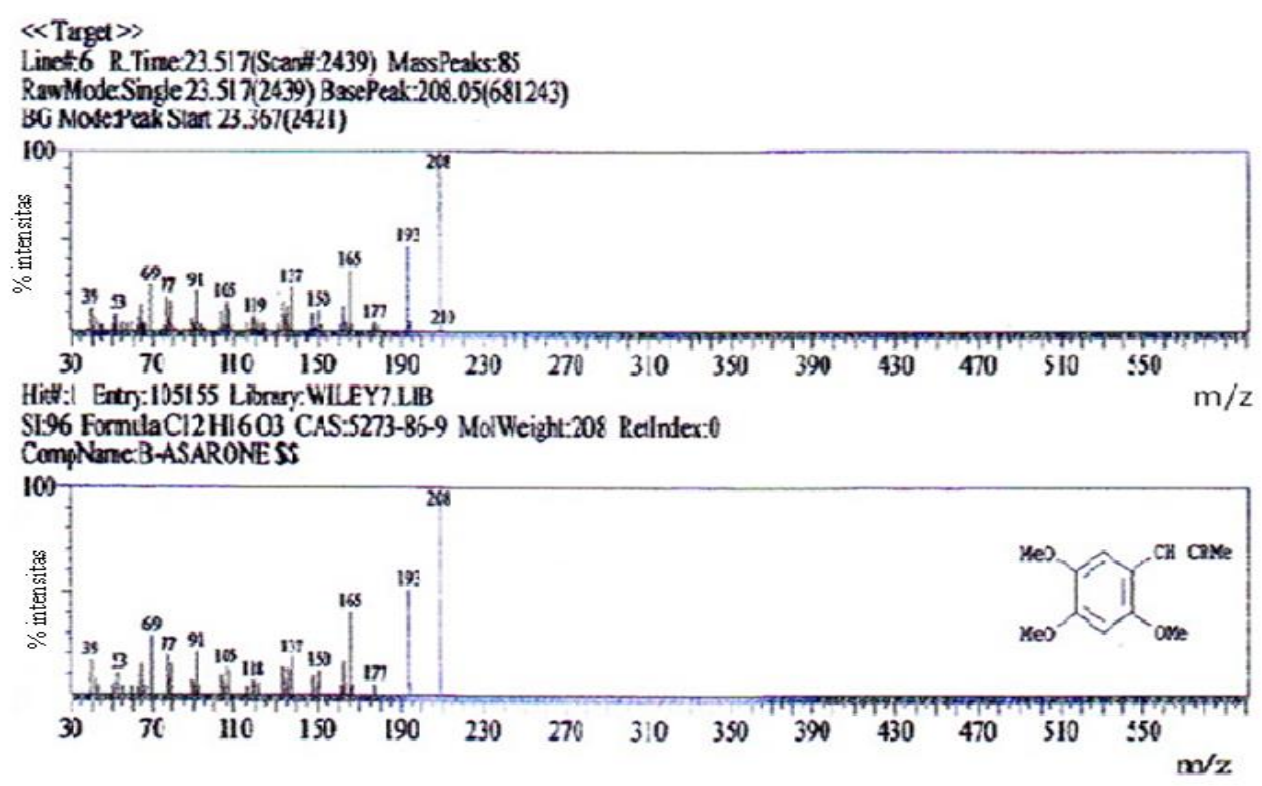

Gambar 2. Spektra massa puncak 6 dan spektra massa referensi asaron

Analisis spektra massa (Gambar 2) menunjukkan bahwa puncak 6 dengan presentase $89,81 \%$ adalah senyawa asaron. Dari spektra massa di atas diketahui bahwa indeks kesesuaian (SI) antara spektra massa puncak 6 dengan spektra massa referensi asaron sangat tinggi yaitu $96 \%$. Hal ini menjelaskan bahwa dalam minyak batang genoak terdapat senyawa asaron dengan kadar yang tinggi yaitu $89,81 \%$. Asaron merupakan senyawa yang paling banyak terkandung dalam batang genoak. Adapun fragmentasi spektra massa puncak 6 disajikan pada Gambar 3 .<smiles>CC=Cc1cc(OC)c(OC)cc1C=CC</smiles><smiles>C/C=C/c1ccc(OCCOc2cc(OCC)c(OC)cc2/C=C/C)cc1OCC</smiles><smiles>C/C=C\I(C)c1ccc(OC)cc1OCCO</smiles>

Gambar 3. Fragmentasi spektrogram massa puncak 6 
Dari pola fragmentasi sebagaimana gambar di atas, base peak adalah fragmen molekul dengan $\mathrm{m} / \mathrm{z}=$ 208 yang juga bersesuaian dengan massa molekul relatif adalah senyawa asaron. Hal ini menunjukkan bahwa senyawa asaron merupakan molekul yang stabil. Adapun massa $\mathrm{m} / \mathrm{z}=210$ merupakan puncak isotop hidrogen. Hal ini diketahui dari perbandingan tinggi puncak $\mathrm{m} / \mathrm{z}=208$ dengan $\mathrm{m} / \mathrm{z}=201$ yang bersesuaian dengan perbandingan isotop ${ }_{1}^{1} H$ dengan ${ }_{1}^{2} D$.

Puncak fragmen molekul dengan kelimpahan cukup tinggi ditunjukkan oleh puncak $\mathrm{m} / \mathrm{z}=193$. Kestabilan molekul ini disebabkan stabilisasi muatan melalui resonansi yang banyak.

\section{b. Hasil Uji Aktivitas Antibakteri Escherichia coli}

Pada penelitian ini, aktivitas antibakteri minyak atsiri batang genoak diuji terhadap bakteri Escherichia coli dengan konsentrasi $10^{-4}$ koloni/mL. Pemilihan konsentrasi ini didasarkan pada metode uji antibakteri hitung cawan (Plate Count). Konsentrasi bakteri yang dapat digunakan untuk pengujian antibakteri adalah konsentrasi pengenceran tertinggi yang dapat memberikan jumlah bakteri terhitung. Oleh karena itu dalam penelitian ini konsentrasi bakteri $E$. coli yang digunakan diperoleh pada pengenceran $10^{-4}$.

Dari hasil pengenceran bakteri mulai dari cawan $10^{-1}$ sampai $10^{-3}$ tidak dapat dihitung karena bakteri yang tak terhingga jumlahnya (spreader). Adapun pengenceran $10^{-4}$ diperoleh konsentrasi bakteri terhitung pada 297 koloni. Dari hasil yang diperoleh telah diketahui bahwa pengenceran yang akan digunakan untuk menguji aktivitas antibakteri yaitu pada volume pengenceran $10^{-4}$, sedangkan pada volume pengenceran $10^{-5}$ sampai $10^{-10}$ tidak digunakan untuk menguji antibakteri karena bakteri yang tumbuh sangat sedikit.

Tabel 2. Pengenceran bakteri E. coli dengan menggunakan media PCA, suhu $37{ }^{\circ} \mathrm{C}$ dalam waktu 24 jam.

\begin{tabular}{|c|c|c|c|}
\hline $\begin{array}{c}\text { Volume } \\
\text { pengenceran } \\
(\mathbf{g})\end{array}$ & $\begin{array}{c}\text { Cawan } \\
\text { I }\end{array}$ & $\begin{array}{c}\text { Cawan } \\
\text { II }\end{array}$ & Total \\
\hline $10^{-1}$ & $\mathrm{Tt}$ & $\mathrm{Tt}$ & $\mathrm{Tt}$ \\
\hline $10^{-2}$ & $\mathrm{Tt}$ & $\mathrm{Tt}$ & $\mathrm{Tt}$ \\
\hline $10^{-3}$ & $\mathrm{Tt}$ & $\mathrm{Tt}$ & $\mathrm{Tt}$ \\
\hline $\mathbf{1 0}^{-4}$ & $\mathbf{1 5 5}$ & $\mathbf{1 4 2}$ & $\mathbf{2 9 7}$ \\
\hline $10^{-5}$ & 31 & 28 & 59 \\
\hline $10^{-6}$ & 11 & 12 & 23 \\
\hline $10^{-7}$ & 6 & 5 & 11 \\
\hline $10^{-8}$ & 1 & 2 & 3 \\
\hline $10^{-9}$ & 0 & 0 & 0 \\
\hline $10^{-10}$ & 0 & 0 & 0 \\
\hline Blanko media & & & 0 \\
\hline
\end{tabular}

Keterangan :

$\mathrm{Tt}$ : bakteri yang tumbuh tak terhitung jumlahnya

PCA : Plate Count Agar 
Aktivitas antibakteri E. coli pada minyak atsiri... (Sherlly M. F. Ledoh, dkk.)

Tabel 3. Konsentrasi minyak genoak dan rerata jumlah koloni yang tumbuh.

\begin{tabular}{|c|r|r|r|}
\hline \multirow{2}{*}{$\begin{array}{c}\text { Konsentrasi } \\
\text { minyak genoak } \\
(\% \text { v/v) }\end{array}$} & \multicolumn{2}{|c|}{$\begin{array}{c}\text { Jumlah koloni yang } \\
\text { tumbuh }\end{array}$} & \multirow{2}{*}{ Rerata } \\
\cline { 2 - 3 } & Cawan I & Cawan II & \\
\hline 0 & 128 & 132 & 130 \\
\hline 2 & 46 & 44 & 45 \\
\hline 4 & 32 & 34 & 33 \\
\hline 6 & 16 & 18 & 17 \\
\hline 8 & 10 & 9 & 9,5 \\
\hline 10 & 5 & 6 & 5,5 \\
\hline
\end{tabular}

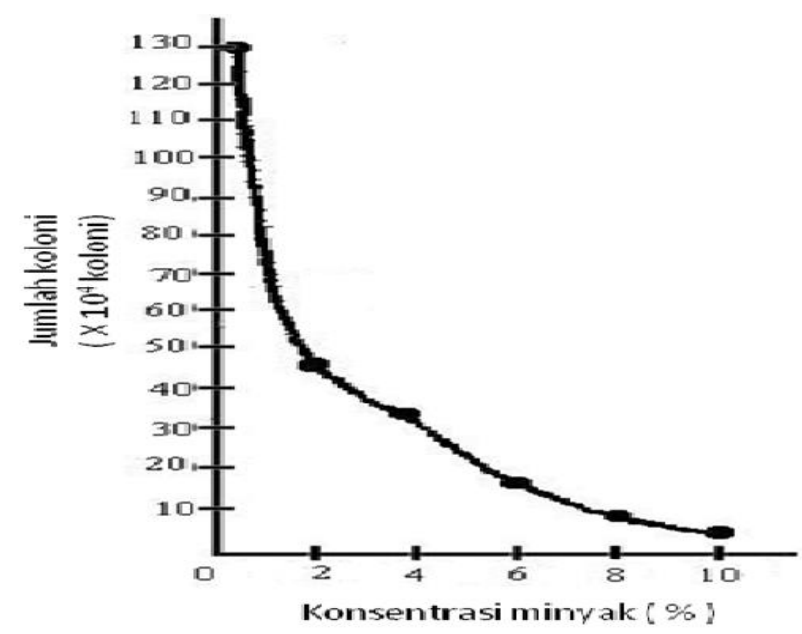

Gambar 4. Grafik daya hambat minyak genoak terhadap E. coli

Dari hasil pengamatan menunjukkan bahwa minyak atsiri batang genoak (Acorus calamus) dapat menghambat pertumbuhan bakteri E. coli besarnya daya hambat bakteri E. coli pada konsentrasi $10 \% \mathrm{v} / \mathrm{v}$ adalah sebesar 95,76\%. Dengan demikian uji aktivitas antibakteri dapat disimpulkan bahwa semakin besar konsentrasi sampel semakin berkurang jumlah bakteri $E$. coli yang tumbuh.

\section{KESIMPULAN}

Berdasarkan penelitian yang telah dilakukan diperoleh kesimpulan bahwa minyak atsiri batang genoak (Acorus calamus) mengandung asaron sebesar $89,81 \%$ dan memiliki aktivitas antibakteri $E$. coli dengan daya hambat pertumbuhan bakteri sebesar 95,76\% pada konsentrasi $10 \%(\mathrm{v} / \mathrm{v})$.

\section{DAFTAR PUSTAKA}

Bhuvaneswari, Rajagopal, 2012, Antibacterial Activity of Acorus Calamus and Some of its Derivatives Against Fish Pathogen Aeromonas Hydrophila, Indian Journal of Fundamental and Applied Life Sciences, Vol. 2 (2), pp. 191- 201

Ferdiansyah, F., 2003, Penetapan Beberapa Parameter Kualitas Ekstrak dan Gambaran Kromatografi Gas-Spektrometri Massa 
Molekul, Vol. 8. No. 1. Mei, 2013: 1 - 8

Minyak Atsiri Rimpang Dringo (Acorus calamus L.) Skripsi FMIPA, UNPAD, Bandung.
Waluyo, L., 2008, Teknik Dan Metode Dasar Dalam Mikrobiologi, UMM Press, Malang.

Iswanto, H., 2003, Permintaan Calamus

Oil Tinggi Pasok Rendah, Harian

Umum Bisnis, Jakarta 